\title{
Conferência/Lecture
}

\section{Concepts of liberty and value pluralism: Implications for psychiatry*1}

\author{
Claudio E. M. Banzato*2
}

\begin{abstract}
Isaiah Berlin's distinction between the ideas of 'positive' and 'negative' liberty is examined within the context of his value pluralism, in which goods, evils and forms of life are ultimately incommensurable (or incomparable through reasoning). Adopting this pluralist stance as to values, I try to answer the following question: does psychiatry need to/is it able to reach an explicit agreement as what is the best way to live? Given the precedence of practical reasoning in psychiatry, I suggest that, when confronted with certain kinds of human suffering (pathos), often associated with a clash between values, the last word (however tentative and always individual) should come from the clinical realm.
\end{abstract}

Key words: Isaiah Berlin, values, psychiatry, clinical practice

*1 Plenary lecture delivered on 7 October 2008 at the INPP Psychiatry \& Freedom Conference in Dallas, USA, and published here for the first time.

*2 Department of Psychiatry, Medical School, University of Campinas (Unicamp), Campinas, SP, Br. 


\section{CONFERÊNCIA/LECTURE}

As far as I know, the works of the British philosopher and historian of ideas Isaiah Berlin (actually born in Russia in 1909; he died in Oxford in 1997) have not been considered as yet in this recent and vigorous reappraisal of the role of values in psychiatry. Though the Berlin philosopher seems to have been to a great extent overshadowed by the masterful historian of ideas he undoubtedly was, to my mind, some of Berlin's core political theses are as subtle as rich and powerful in their consequences. Of course it is way beyond the scope of this lecture to give a full account of his philosophy. For those who want a systematic and articulated presentation of his ideas, I would recommend the book "Isaiah Berlin" by John Gray (published in 1996 by the Princeton University Press), whose arguments I find mostly compelling. Interestingly, as it turns out, the Berlin who emerges from Gray's analysis, due to Berlin's unceasing and unflinching commitment to pluralism, has much of the genuine fox he certainly was, but something of a hedgehog too (to use his own famous analogy, which draws from a line of the Greek poet Archilochus: "The fox knows many things, but the hedgehog knows one big thing").

What I intend to do here is first to point out the key distinction suggested by Berlin between two broad senses of the term 'liberty', a 'positive' and 'negative' one (this distinction was put forward by him in the well-known and controversial article "Two Concepts of Liberty", published in 1958). Second, I aim at clarifying what makes, to my mind, Berlin's value pluralism special and appealing, as well as to connect it somehow to the prominence given by him to the negative sense of liberty. [Though Berlin's main concern in that lecture is political pluralism, I think his basic ideas about values have far-reaching moral consequences as well.] Then, after having attempted to sketch a minimalist and coherent Berlinian framework, I will try to examine some possible implications of adopting such view, and I will do that by addressing (in a rather tentative way, I am afraid) a few related questions, which cannot be bypassed if what is at stake is the very nature of our discipline: what is (are) the implicit 'order(s)' assumed by psychiatric theory and practice, so the talk about 'disorders' may make sense and whether or not psychiatry actually needs and can afford an agreed and spelled out conception of what it is the best way to live. I find these questions pretty germane to the theme of this conference. 
A caveat is in order here: during this lecture, especially in the first part, I will inevitably use several disputed philosophical terms and refer to many controversial philosophical topics, without however addressing them in any finegrained fashion most of the times. I will limit myself to trying to draw the main contours of Berlin's central ideas.

Let us start with the distinction between the 'positive' and the 'negative' political senses of liberty. Berlin fully recognizes the protean character of the word 'liberty' and does not set himself to explore its countless senses throughout history, selecting for his exam just two of them, which he claims are those central ones. He does not perform a semantic analysis either and, for his purposes, both words 'liberty' and 'freedom' are used to mean the same. [Anyway, maybe it is worth mentioning en passant the very first entry for each of these words in the Oxford English Dictionary: liberty: exemption or release from captivity, bondage, or slavery; freedom: exemption or release from slavery or imprisonment; personal liberty.]

Berlin's insightful suggestion is that there are two clearly different questions whose answers (admittedly, overlapping to some extent) are involved with what he henceforth calls the 'negative' and the 'positive' political senses of liberty. The questions are respectively:

What is the area within which the subject - a person or group of persons - is or should be left to do or be what he wants to do or be, without interference by other persons? [and] What, or who, is the source of control or interference, that can determine some one to do, or be, one thing rather than another? (pp. 121-122)

So, interference is a central word in both senses, not any kind of interference though, but deliberate interference by other human beings - that is, some sort of coercion - preventing one from doing whatever he or she wants and determining what should be done instead. The 'negative' sense concerns the existence of a minimum area (with recognizable boundaries) within which the individual is free to act and to pursue his or her goals as he or she wishes. Therefore, liberty in this sense means essentially liberty from. In the 'positive' sense, liberty derives from the wish to be one's own master, that is, self-governed, a subject not an object. It is not only matter of having a free area of action, but also of actually being in control; not just freedom from, but freedom to.

The point here is not to merely stipulate different meanings for the word 'liberty', nor to establish any sharp and artificial separation between two notions obviously connected, but to show that there are different elements logically operative in the grammar of each sense and that they are bound to entail far-reaching consequences. According to Berlin, "the 'positive' and 'negative' notions of freedom developed in divergent directions until, in the end, they came 


\section{CONFERÊNCIA/LECTURE}

into direct conflict with each other" (p. 132); for him, this very distinction played a decisive role in the clashes of ideologies that dominated the past century. Berlin's thesis is that the 'positive' notion throughout history has revealed itself particularly prone to abuse by providing a specious disguise for brutal tyranny. How that can be, perhaps one may ask? How such a dramatic distortion could have ever taken place?

The gist of the problem is the way certain idealized concepts have been often used both to define the stance responsible for self-mastery and what should count as its actual realization. In Berlin's own words,

(...) this dominant self is then variously identified with reason, with my 'higher nature', with the self which calculates and aims at what will satisfy it in the long run, with my 'real', or 'ideal', or 'autonomous' self, or with my self 'at its best'; which is then contrasted with irrational impulse, uncontrolled desires, my 'lower' nature, the pursuit of immediate pleasures, my 'empirical' or 'heteronomous' self, swept by every gust of desire and passion, needing to be rigidly disciplined if it is ever to rise to the full height of its 'real' nature. (p. 132)

What lies at the core of Berlin's concern (something that particularly worries him) is the political implications of having this idealized stance assimilated by any sort of collective body. According to him, this talk about the 'true' or 'real' or 'ideal' self provides the vocabulary and prepares the political terrain, so to speak, to an even deeper chasm as

(...) the real self may be conceived as something wider than the individual (as the term is normally understood), as a social 'whole' of which the individual is an element or aspect: a tribe, a race, a church, a state, the great society of the living and the dead and the yet unborn. This entity is then identified as being the 'true' self which, by imposing its collective, or 'organic', single will upon its recalcitrant 'members', achieves its own, and, therefore, their, 'higher' freedom. (p. 132)

The extreme corollary of such position is that

(...) once I take this view, I am in a position to ignore the actual wishes of men or societies, to bully, oppress, torture them in the name, and on behalf, of their 'real' selves, in the secure knowledge that whatever is the true goal of man (happiness, fulfillment of duty, wisdom, a just society, self-fulfillment) must be identical with his freedom — the free choice of his 'true', albeit submerged and inarticulate, self. (p. 133)

In short, if I 'know' what it is best for the others, it does not take much to see my coercion of others as something I do for their own sake, in their, not my interest.

Like one of his (and mine too) intellectual heroes, the sophisticated libertarian Russian Alexander Herzen of the XIX century, Berlin was deeply suspicious of certain highly regarded abstractions, such as history, progress, and 
social equality, bound to produce evil consequences. In particular, both of them have strongly rejected abstractions that embodied general solutions to human problems or universal ends for human life.

It is a truism that freedom is not the only aspiration of human beings (and conceivably it might not be the main driving force for the majority of them). But nothing is to be gained, says Berlin, by conflating other aspirations, for instance, the want of equality and fairness or the desire for status and recognition, with liberty. Furthermore, he strongly opposes the assimilation of liberty either with reason or with virtue, a more likely step if one adopts a rationalist and monist conception of good, precisely the view that Berlin rejects. As a matter of fact, as it will become clear later on, Berlin holds a pluralism of both goods and evils. Berlin does distrust a certain conception of reason as if it were a magic eye that can see universal, non empirical truths, and argues against the idea of rigid boundaries set once and for all by reason, what he calls the metaphysical heart of rationalism: "to want necessary laws to be other than they are is to be prey to an irrational desire (...). To go further, and believe these laws to be other than what they necessarily are, is to be insane" (p. 144).

His main target, however, is not this conception of reason in itself, but its coupling with the belief that "all true solutions to all genuine problems must be compatible: more than this, they must fit into a single whole: for this is what is meant by calling them all rational and the universe harmonious" (p. 147). Thus, the idea of a law-like rational necessity of having one and only one true solution to each question (even if we do not or cannot know it) is challenged. When it comes to central values such as ethical, aesthetic, social, and political, Berlin, a liberal rationalist himself, underscores what he thinks are the main contributions from the counter-Enlightenment: the beliefs that science and reason do not have all the answers and that there can be more than one valid answer. So, for him there is no such a thing as a final and harmonious solution similar to the one of a jigsaw-puzzle, which should lead to a perfect life. The formula that embodies such expectation and that is dismissed as fundamentally misleading by Berlin thus reads: if you know what life really is, then you know what to do. It echoes Hume's adage "no ought from an is".

For Berlin, there is much more in liberty than the mere freedom to obey a rational will. As Gray (1996) aptly put it, summarizing Berlin's account, the persons must be free not to make the right choices, but to make the choices they make. The underlying belief is that choice is indeed a radical matter. That is to say, decisions about forms and ends of life cannot be founded on any self-evident truth or knockdown reason. But these choices between ultimate values do not take place in a vacuum either and they are not groundless at all, they actually hinge on moral categories and concepts that are part of the persons own identity, part 


\section{CONFERÊNCIA/LECTURE}

of what makes them human. In this scenario, radical choices are thus part of the make up of selfhood itself. For this philosopher of liberty, selfhood is a matter of invention rather than of discovery.

This issue brings us closer to the consideration of the type of value pluralism held by Berlin, within which there are noncontingent conflicts between values, either incompatibility or opposition, and incommensurability. From the outset, it should be said that Berlin appears to be a realist about values and this is what makes his position very interesting philosophically (as Thomas Nagel (2001) and Charles Taylor (2001), for instance, have admitted). Though he has a sharp eye for history and diversity, he is not exactly a moral relativist. Of course he acknowledges without any problem the fact that each culture has different ideals, which are final for each of them, that there are certain values and ideals at the very center of gravity of any given culture. But, for him, values, however diverse, are not infinite. They would belong to some sort of common horizon shared by humankind. And that is precisely what renders possible communication between individuals, groups, cultures. So there is this tension about his pluralism: should it be taken as a value or an empirical description of the world? The following passage from the end of his essay on the concepts of liberty is illuminating in that respect:

(...) pluralism, with the measure of 'negative' liberty that it entails, seems to me a truer and more humane ideal than the goals of those who seek in the great, disciplined, authoritarian structures the ideal of 'positive' self mastery by classes, or peoples, or the whole of mankind. It is truer, because it does, at least, recognize the fact that human goals are many, not all of them commensurable, and in perpetual rivalry with one another. (p. 171)

Though the main focus of Berlin's analysis is the concept of political liberty, at the bottom of his pluralist stance what is really at stake is not the question about conflict of values between persons or societies, but the conflict that lies within one consciousness. But again, he does not mean just to point out platitudes such as the multiplicity of human interests and the impossibility of pursuing them all in a single lifetime span. His pluralism has far-reaching consequences for the very idea of fulfillment of human life. In his words:

(...) but somewhere, we shall be told; and in some way, it must be possible for all these values to live together, for unless this is so, the universe is not a cosmos, not a harmony; unless this is so, conflicts of values may be an intrinsic, irremovable element in human life. To admit that the fulfillment of some of our ideals may in principle make the fulfillment of others impossible is to say that the notion of total human fulfillment is a formal contradiction, a metaphysical chimaera. (pp. 167-168)

What is rejected by him is the deeply-rooted belief (actually, a metaphysical longing) that an a priori guarantee of the proposition that a total harmony of true 
values must be found somewhere. For him no conception of good or any 'abstract order' should be hypostasized. Instead,

(...) ordinary resources of empirical observation and ordinary human knowledge (...) give us no warrant for supposing (or even understanding what would be meant by saying) that all good things, or all bad things for that matter, are reconcilable with each other. The world that we encounter in ordinary experience is one in which we are faced with choices between ends equally ultimate, and claims equally absolute, the realization of some of which must inevitably involve the sacrifice of others. (p. 168)

John Gray (1996) calls this view an agonistic pluralism: the point being not only the trivial impossibility of attaining perfection in life or the inevitability of a certain psychological sense of loss or suffering, which derives from the decisions. For Berlin, "the necessity of choosing between absolute claims is then an inescapable characteristic of the human condition" (p. 169). And emphasis must be put on the expression 'absolute claims', which means that different values, however conflicting between each other they might be, are binding on us somehow. The neuralgic center of Berlin's tragic position is that some degree of wrongness is tied up with choices to the extent that no decision is right.

Along with his dismissal of the belief in the conciliating power of any single formula or criterion to resolve ultimate conflict of values, Berlin rejects the very idea of a higher vantage point of evaluation. For him, there is no such a thing as a meta-theory or over-arching principle that determines how conflicts between incommensurable values (not only conflicts between 'positive' and 'negative' liberties or between different 'negative' liberties themselves, but also those ones involving other central values such as liberty and justice etc.) are to be resolved. Instead, he advocates that these conflicts must be dealt with on a piecemeal basis in concret circumstances. So, Berlin seems to appeal to the ancient notion of practical wisdom.

It is true that Berlin gives preeminence to liberty (especially in the 'negative' sense), but this does mean that liberty should be thought as a value that necessarily trumps the others. Nor does he claim that it is an ideal with eternal validity. Actually, for him, it is simply off the mark to seek guarantees that our values should transcend history. Within this Berlinian framework, the key value attached to the freedom to choose ends and the defense of such kind of value pluralism are mutually supportive; they seem to reinforce one another. Taken together, these two ideas do not, to my mind, have relativistic implications, not at least in a strong sense of relativism. If life is tragic and our choices are bound to generate some wrongness, this is not a call for extreme measures. Quite on the contrary, for Berlin, once the radical character of the choices is fully acknowledged, what follows is a plea for moderation, that is, close consideration 


\section{CONFERÊNCIA/LECTURE}

of all things at stake in a given concrete situation and careful judgment without the biases derived from the harmful prejudice that perfect or final solutions must always be possible.

So what I am going to do next is precisely to exam how such conception about values might affect one particular kind of concrete situation, the clinical encounter. Though both psychiatric theory and practice will be addressed somehow, emphasis will be given to the latter, to what actually happens in the clinical realm. I hope the brief sketch of Berlin's ideas just presented will suffice for such a purpose.

Let us move then to the second part of this lecture and seek for some possible implications for psychiatry of adopting such value pluralist stance. But one may ask what do I mean by psychiatry in the first place? I think the broad definition provided by German Berrios (2007) works pretty well: "psychiatry names a set of loosely connected disciplines and doings related to the understanding and management of human afflictions". It must be added that, for him, "such understanding encompasses intellectual, emotional and aesthetic apprehension of their context, history, meaning and biology". Psychiatry would be thus a conceptual 'hybrid', to the extent that its structures and narratives are provided by both natural and human sciences.

As a modificatory discipline, rather than a contemplative one, psychiatry must have a set of assumptions about what should be pursued by its interventions. As my colleague Mario Pereira (personal communication) aptly put it: if we conceptualize certain human predicaments as mental 'disorders' and therapeutically target them, we necessarily must have a good grasp of which is the underlying mental 'order' to be restored. Yet, this issue has typically remained implicit as if there was a tacit agreement about it. I suspect that, most of times, in contemporary psychiatry, it is assumed the existence of a natural order of things (and by 'natural' it is usually meant, at the bottom, biological) that can be disrupted or broken down in some specific ways, which might be objectively described as 'dysfunctions'. But the limitations of narrowing down the analysis of mental disorders in terms of 'function' (the 'doing' word associated with parts) have already been pointed out by Bill Fulford (2001) in his open letter to Christopher Boorse and several other writings. A convincing case is made by him against an account of paradigmatic mental disorders such as schizophrenia strictly based on the notion of 'dysfunction'. Their proper analyses would involve organisms and functioning as well as subjects (or agents) and action. This view seems to do better justice to the inherent complexity of psychiatry. So, if biology alone clearly is not enough for setting the benchmarks for the conceptualization of mental disorders, if a broader framework is required because the 'order' supposed by psychiatry is either a very complex one or manifold, what else should be considered? 
Berrios (2007) has argued that it is crucial to identify the often hidden concept of man that governs clinical practice and research. According to him, psychiatry does need a philosophical anthropology given the fact that all forms of psychiatry presuppose a concept of 'man' and are indeed meaningless and impotent without such a concept, as it provides psychiatry with epistemological, ethical, aesthetic and pragmatic governance. However important it may prove to be, a concept of man isolated is not enough. It must be coupled with an account of what should constitute a fulfilled life (eudaimonia). As a matter of fact, I must acknowledge that the one of the main inspirations for this lecture came from a sharp observation made by John Sadler in his book "Values and Psychiatric Diagnosis" (2005): "psychiatrists work toward helping people with all manner of maladies, from problems-in-living to chronic, debilitating diseases; but what the profession, and its practitioners, believe about the best way to live is their best-kept secret" (p. 5).

Nevertheless, while unpacking and dealing with all kinds of operative values involved in the psychiatric enterprise is a crucial step if we are to take seriously the profession's intrinsic complexities and daunting challenges, amid its many practical shapes and intellectual traditions, it does not follow that psychiatry should seek to become some sort of unifying normative stance. This point connects with our earlier examination of Berlin's value pluralism. It is crystal clear that certain operative conceptions (however tacit they may be) of how to live are always present in any clinical encounter and it may well be that there are as many conceptions in play as the number of the persons involved in a given situation. But for the profession to offer a collective answer to the question of how to live, that is, to hold a single concept of eudaimonia, that would require the hypostasis (or substantiation) of a certain rational order. And that is precisely what should be feared within a Berlinian framework. Perhaps another way to put it is found in Bill Fulford's book chapter "Ten Principles of Value-Based Medicine (VBM)" (published in 2004), another key inspiration for the present lecture. His remark (emphatically repeated throughout his paper) reads: "the point is that human values are not, merely, different but legitimately different" (p. 215)

But one may ask what does actually the word 'legitimate' stand for in this context? What does it mean to affirm that the values are legitimately different? Fulford suggests that such legitimacy follows analytically from the logical separation between fact and value (that is, of description and evaluation) insisted on by 'non-descriptivism' in philosophical value theory. He also points out that there are areas of human experience and behavior, such as emotion, desire, volition, belief, in which human values are highly diverse. Needless to say that these areas are the ones psychiatry is mostly concerned with. Berlin's defense of this space within the subject free of interference of others (liberty in the 'negative' sense) might offer yet another rationale for this thesis. 


\section{CONFERÊNCIA/LECTURE}

What I want to do next is to briefly examine whether or not such use of 'legitimate' for difference of values could be thought to hinge on claims related to the canons of 'rationality', particularly with respect to human action. In a strong sense of rationality, an action is rational only if it is required by reason and if not to perform it should be declared irrational. In a weak sense, there is still some normative command: rational are the options either rendered or at least not rule out or precluded by reason. Thus, a 'legitimate' difference could conceivably be taken to mean a rational difference, in the weak sense.

In this scenario, the boundaries (however imprecise) of what should count as 'legitimate' beliefs, behaviors and actions are to be set out by reason. Rationality would provide with an underlying order, which might be disrupted in the case of mental disorders. Differences of values would then be thought as 'legitimate' as long as a given rationality criterion is met. But one should ask: could rationality possibly be expected to play such normative role in psychiatry? I do not believe so. And that is precisely the core of our problem: mental disorders do not necessarily imply a rational breakdown or must have an irrational element at their core. But they are not simply bad choices either, that is, choices contrary to all-things-considered or better judgment. Still, how to tell the difference between them? I would like to suggest that such distinction is based somehow on the presence of an element of 'constraint'. In the case of mental disorders, it is as if the free area within the person had shrunk, and so the individual ends up with an inability to do otherwise if he or she wanted to, to act in accordance with his or her most heartfelt desires; the subject lacks responsiveness to his or her own reasons. It becomes hard for the agent to go beyond a given norm (which may have worked before) in a world that is constantly changing, that is, there would be at least a narrowing of the repertoire of choices or even, in more severe conditions, no choice at all, only compulsion. In other words, reduction or loss of freedom.

If we accept Berlin's idea that conflicts or clashes of values are inevitable and incommensurability is widespread (that is, that values often cannot be either compared or reconciled by reason), we must face radical choices about forms and ends of life that are bound somehow to generate some wrongness, which means that liberty (especially in the 'negative' sense) is a critical political value. On the other hand, if compulsion is a conspicuous feature of mental illness, shrinking the free area within the subject and threatening the very sense of autonomy and self-mastery, reducing the person's liberty to pursue whatever he or she considers being meaningful, the question about the legitimacy of the values of a mentally ill person becomes tremendously pressing. That is why I dare to suggest that what is indeed key in any clinical encounter is that no a priori answer should define its course and outcome, that the values of the person who seeks mental health care 
should not be dismissed or downplayed in favor of a certain collective ideal (be it the ideal of the profession - psychiatry - or the values of society at large). If such collectively held ideals take over, that is, if they are converted into a sort of evaluative clockwork, then it is just a small step to impose a certain view to the patients, claiming that we know better what is best for them. Needless to say, the presence of a compulsion is not sufficient to justify coercion. Actually, it is necessary always to keep in mind that loss of freedom may result either from mental illness or from psychiatric treatment. Not rarely, from both at the same time. [Unsurprisingly, discriminating grounds and circumstances associated with coercion is a thorny issue addressed by several papers at this conference.]

This is psychiatry's paradox and predicament. It is not just about having to choose the lesser of two evils. It goes way beyond that; borrowing from Berlin, it is knowing well that sometimes no decision feels completely right. Thus, the critical importance that the process of decision-making takes place at the clinical forefront (where it actually belongs), so it may allow all those involved in a unique clinical encounter (clinicians and patients alike) have their say, participating somehow of the process of reaching a decision. This is, by the way, one of the principles of the values-based practice put forward by Fulford (2004), 26 and I must add, one of its main strengths.

What I am suggesting is the centrality of the clinic, so that the last word (however tentative and always individual) must be given within the clinical realm. This means accepting the primacy of practical reasoning. Psychiatry is certainly a risky business and clinicians cannot help being, in a way, blade runners. Sticking to the blade metaphor, we can put it differently with the help of the great Portuguese poet Fernando Pessoa, who wrote in his "The Book of Disquiet": "None of us can untie the Gordian knot; either we give up or we cut it". Psychiatrists are confronted with concrete human suffering (and I would like to mention Georges Canguilhem's remark, extracted from his classic book The Normal and the Pathological, published in 1943) that "pathology implies pathos, the direct and concrete feeling of suffering and impotence, the feeling of life gone wrong" (p. 85). For the French philosopher of medicine and life sciences, pathos takes precedence over logos and, when it comes to pathology, "the first word, historically speaking, and the last word, logically speaking, must belong to the clinic" (p. 153)

I hope I have offered you a minimally coherent sketch of Berlin's central ideas about liberty and pluralism as well as indicated that they may constitute an interesting framework for us to think about the formidable challenges that we are confronted with in the mental health field. Thank you very much for your attention. 


\section{CONFERÊNCIA/LECTURE}

\section{References}

Berlin, I. (1969). Two Concepts of Liberty. In Isaiah Berlin's Four Essays on Liberty (pp. 118-172). Oxford: Oxford University Press. (Original work published in 1958).

Berrios, G. (2007, oct.). Does Psychiatry 'need' a Philosophical Anthropology? XXV Brazilian Congress of Psychiatry, Porto Alegre.

Canguilhem, G. (2007). Le normal et le pathologique. Paris: PUF. (Original work published in 1943).

Gray, J. (1996). Isaiah Berlin. Princeton: Princeton University Press.

Fulford, K.W.M. (2001). 'What is (mental) disease?': an open letter to Christopher Boorse. Journal of Medical Ethics, 27(2), 80-85.

Fulford, K.W.M. (2004). Facts/Values: Ten Principles of Values-Based Medicine. In J. Radden (Ed.). The Philosophy of Psychiatry - A Companion (pp. 205-234). Oxford: Oxford University Press.

Nagel, T. (2001). Pluralism and Coherence. In R. Dworkin, M. Lilla \& R.B. Silvers (Eds.). The Legacy of Isaiah Berlin (pp. 105-111). New York: NYRB.

Sadler, J.Z. (2005). Values and psychiatric diagnosis. Oxford: Oxford University Press.

Taylor, C. (2001). Plurality of Goods. In R. Dworkin, M. Lilla \& R.B. Silvers (Eds.). The Legacy of Isaiah Berlin (pp. 113-119). New York: NYRB.

\section{Summary}

(Conceitos de liberdade e pluralismo de valores: implicações para a psiquiatria)

A distinção de Isaiah Berlin entre as noções de liberdade 'positiva' e 'negativa' é examinada no contexto de seu pluralismo de valores, em que bens, males e formas de vida são, em última instância, incomensuráveis (ou incomparáveis pela razão). Adotando esta posição pluralista sobre valores, tento responder às questões: a psiquiatria precisa elou consegue chegar a um acordo explicito sobre qual é a melhor maneira de viver? Dada a prioridade da razão prática em psiquiatria, sugiro que, quando confrontados com certos tipos de sofrimento humano (pathos), que não raro envolvem conflitos de valor, a última palavra (por provisória que seja e sempre individual) deve pertencer ao campo da clínica.

Palavras-chave: Isaiah Berlin, Valores, Psiquiatria, Prática Clínica 
(Conceptions de la liberté et pluralisme des valeurs: implications pour la psychiatrie)

La distinction d'Isaiah Berlin entre les notions de liberté 'positive' et 'négative' est examinée dans le contexte de son pluralisme de valeurs, où les biens, les maux et les modes de vie sont, en fin de compte, incommensurables (ou incomparables du fait de la raison). En adoptant cette position pluraliste sur les valeurs, j'essaie de répondre aux questions: la psychiatrie a-t-elle besoin et/ou peut-elle parvenir à un accord explicite sur quelle est la meilleure façon de vivre? Compte tenu de la priorité de la raison pratique en psychiatrie, je suggère que, face à certains types de souffrance humaine (pathos), qui impliquent souvent des conflits de valeur, le dernier mot (si provisoire soit-il et toujours individuel) doit appartenir au domaine de la pratique clinique.

Mots clés: Isaiah Berlin, valeurs, psychiatrie, pratique clinique

(Conceptos de libertad y pluralismo de valores: implicaciones para la psiquiatría)

La distinción de Isaiah Berlin entre las nociones de libertad "positiva" y "negativa" es examinada en el contexto de su pluralismo de valores, en el que bienes, males y formas de vida son, en una última instancia, inconmensurables (o incomparables por la razón). Adoptando esta posición pluralista relativa a los valores, intento responder a la pregunta: ¿la psiquiatría necesita y/o logra llegar a un acuerdo explícito sobre cuál es la mejor manera de vivir? Dada la prioridad de la razón práctica en psiquiatría, sugiero que, al enfrentarnos con ciertos tipos de sufrimiento humano (pathos), que suelen implicar conflictos de valores, la última palabra (por provisional que sea, es siempre individual) debe pertenecer al campo de la clínica.

Palabras clave: Isaiah Berlin, valores, psiquiatría, práctica clínica

(Konzepte von Freiheit und Wertepluralismus: Implikationen für die Psychiatrie)

Isaiah Berlins Unterscheidung zwischen den Begriffen der „positiven“ und ",negativen" Freiheit wird im Kontext des Wertepluralismus untersucht, wobei Güter, Übel und Lebensformen letztlich inkommensurabel sind (d.h., rational unvergleichbar). Aufgrund dieser pluralistischen Position in Bezug auf Werte, versuchten wir, die folgenden Fragen zu beantworten: muss und/oder kann die Psychiatrie eine ausdrücklichen Konsens darüber erreichen, was die beste Lebensweise ist? Angesichts der hegemonischen Stellung der praktischen Vernunft in der Psychiatrie, schlagen wir vor, dass wenn wir mit bestimmten Arten menschlichen Leidens (Pathos) konfrontiert sind, die oft Wertkonflikte beinhalten, die Klinik das letzte Wort haben sollte (wie vorläufig es sei und immer individuell bestimmt).

Stichwörter: Isaiah Berlin, Werte, Psychiatrie, Klinische Praxis 


\section{CONFERÊNCIA/LECTURE}

（自由和价值多元主义: 对精神分析学的影响）

西方著名的哲学家伊萨亚・柏林（Isaiah Berlin)对自由的定义进行了 " 正” 与 “负”的划分, 他认为人类的价值观是多元的, 有关道德观和生活的方式 等议题, 是” 好” 还是 “坏” , 没有最终的标准（也就说, 凭理性是没有办 法做评判的）。

本文采用柏林的价值观多元主义，尝试回答下列问题：精神分析学需要达 成一个关于什么是最好的生活方式的共识吗? 能够达成这个共识吗? 从精神分 析学所注重的实践理性角度来说, 我认为, 当某些汼涉到价值观冲突的精神病 兆（pathos）出现在我们面前时, 最后的决定取决于临床实践（不管这种临床 的决定是多么的临时性, 个人化)。

关键词：伊萨亚・柏林（Isaiah Berlin）, 价值观, 精神分析学, 临床实践。

Citação/Citation: Banzato, C.E.M. (2016, março). Concepts of liberty and value pluralism: implications for psychiatry. Revista Latinoamericana de Psicopatologia Fundamental, 19(1), $16-29$.

Editores do artigo/Editors: Prof. Dr. Manoel Tosta Berlinck

Recebido/Received: 16,10.2015/ 10.16.2015 Aceito/Accepted: 20.10.2015 /10.20.2015

Copyright: (C) 2009 Associação Universitária de Pesquisa em Psicopatologia Fundamental/ University Association for Research in Fundamental Psychopathology. Este é um artigo de livre acesso, que permite uso irrestrito, distribuição e reprodução em qualquer meio, desde que o autor e a fonte sejam citados / This is an open-access article, which permits unrestricted use, distribution, and reproduction in any medium, provided the original authors and sources are credited.

Financiamento/Funding: Os autores declaram não ter sido financiados ou apoiados / The authors have no support or funding to report.

Conflito de interesses/Conflict of interest: Os autores declaram que não há conflito de interesses / The authors have no conflict of interest to declare.

\section{Claudio E.M. Banzato}

Professor of Psychiatry; Medical School, University of Campinas - Unicamp (Campinas, $\mathrm{SP}, \mathrm{Br})$.

Rua Tessália Vieira de Camargo, 126

Cidade Universitária “Zeferino Vaz" - Barão Geraldo

13083-887 Campinas, SP, Br

e-mail: cbanzato@fcm.unicamp.br

This is an open-access article, which permits unrestricted use, distribution,

\section{(cc) BY-NC} and reproduction in any medium for non-commercial purposes provided the original authors and sources are credited. 